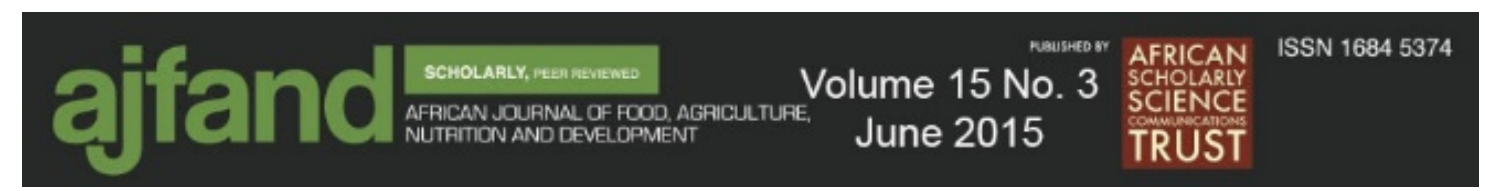

\title{
SELECTED HEAVY METALS IN SOME VEGETABLES PRODUCED THROUGH WASTEWATER IRRIGATION AND THEIR TOXICOLOGICAL IMPLICATIONS IN EASTERN ETHIOPIA
}

\author{
Deribachew $\mathbf{B}^{1^{*}}$, Amde $\mathbf{M}^{2}$, Nigussie-Dechassa $\mathbf{R}^{3}$, AM Taddesse ${ }^{1}$
}

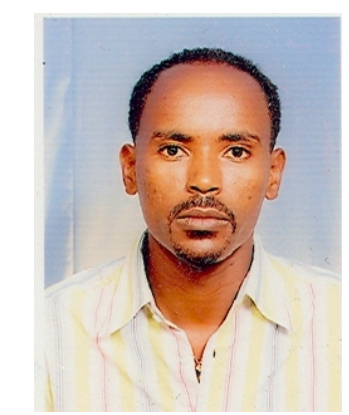

\section{Bekana Deribachew}

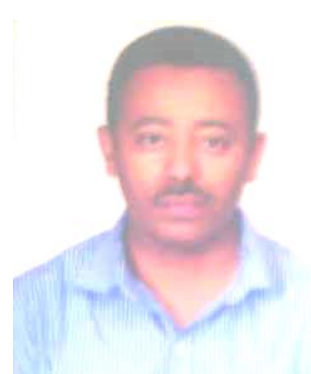

Abi M. Taddesse

*Corresponding author emails: gado430@yahoo.com OR deribachew.bekana@haramaya.edu.et

${ }^{1}$ Department of Chemistry, College of Natural and Computational Sciences, Haramaya University; P. O. Box 138, Dire Dawa, Ethiopia

${ }^{2}$ State key Laboratory of Environmental Chemistry and Ecotoxicology, Chinese Academy of Sciences, P.O. Box 2871, Beijing 100085, China

${ }^{3}$ School of Plant Sciences, College of Agriculture and Environmental Sciences, Haramaya University; P. O. Box 138, Dire Dawa, Ethiopia. 


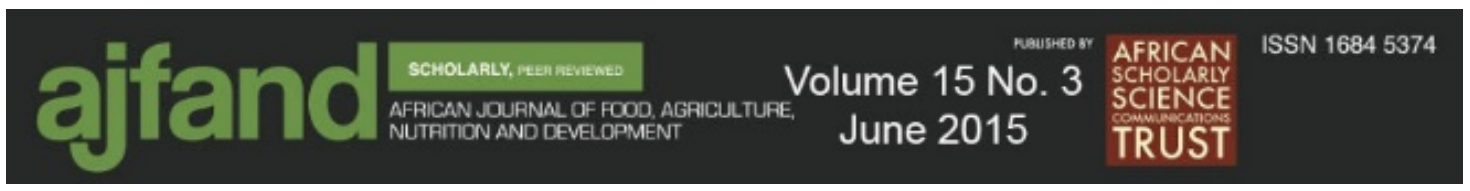

\begin{abstract}
Vegetables widely consumed in some areas of eastern Ethiopia such as cabbage (Brassica oleraceae var. capitata L.), potato (Solanum tuberosum L.), and khat (Catha edulis Forsk.) are cultivated through irrigation with wastewater. The purpose of this study was to analyse the contents of selected toxic heavy metal ( $\mathrm{Cr}, \mathrm{Co}, \mathrm{Cd}$ and $\mathrm{Pb}$ ) of the vegetables, the effluents used to irrigate the crops, and the soils on which the crops were grown, using flame atomic absorption spectrometry (FAAS). The optimized wet digestion procedure was employed to solubilise the metals from the samples. The validation was performed by spiking the samples with a standard solution of each metal having a known concentration and the percentage recovery values in the range of 91.0 $98.3 \%$ for soil, $92.0-102 \%$ for effluent, and $89.0-101 \%$ for vegetable samples. The following concentrations ( $\mathrm{mg} \mathrm{kg}^{-1}$ ) of the metals were found in the edible parts of the cabbage, potato, and khat plants, respectively: Cr [less than method detection limit (<MDL)- 17.13], (11.96-14.21), and (9.04-15.54); Co (5.72-9.72), (5.15-8.72), and (<MDL-8.87); Cd (1.15-2.46), (1.22-1.46), and (0.38-3.22); Pb (5.48-11.95), (5.437.78), and (4.49-11). The concentrations in the effluent samples (mg kg-1) ranged from 0.17-0.26, 0.57-1.02, 0.04-0.08, and 0.82-2.52 for $\mathrm{Cr}$, Co, $\mathrm{Cd}$, and $\mathrm{Pb}$, respectively. Similarly, concentrations (mg kg$)^{-1}$ ) of the metals in the soil samples were in the ranges of 25.71-41.45, 17.69-23.59, 0.79-2.56, and 26.04-47.29 for Cr, Co, and Cd, and Pb, respectively. The study revealed that the concentrations of all metals in the vegetables, except Co, were found to be above the safe limits set by different international organizations for consumption, posing a serious health hazard to humans. Therefore, regular monitoring of effluents, soils, and vegetables are essential to prevent excessive build-up of the toxic heavy metals in food. Thus, the health risk and the extent of heavy metal contamination can be reduced.
\end{abstract}

Keywords: Vegetables, wastewater, safe limits, irrigation 


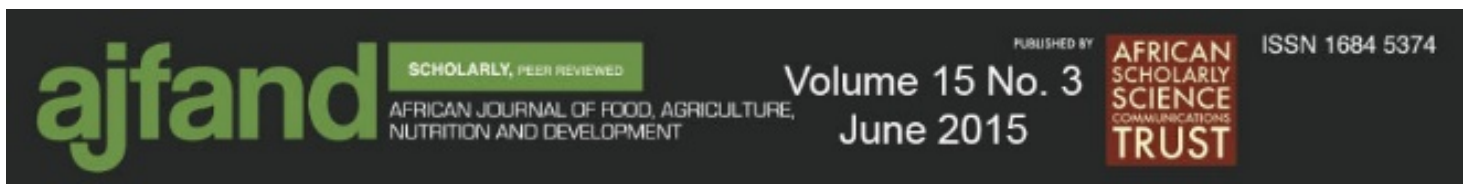

\section{INTRODUCTION}

Vegetables are important ingredients in the human diet and contain essential nutrients and trace elements that have potential health benefits [1]. Environmental pollution has caused the contamination of soil; on the other hand, wastewater irrigation resulted in significant infusion of non-essential elements in agricultural lands [2]. The main cause of the infusion is the waterways through which non-essential elements are leached out of the soil and taken by the vegetation. If plants decay, these potential toxic elements are redistributed, and accumulate in agricultural soils. Long-term irrigation with wastewater leads to a build-up of heavy metals in soils and foods [3].

Exposure of vegetables or plant products to various metal containing components has varying health implications [4]. Furthermore, consumption of food and vegetation contaminated with heavy metals can seriously deplete some essential nutrients in the body causing a decrease in immunological defences, intrauterine growth retardation, impaired psycho-social behaviour, disabilities associated with malnutrition, and a high prevalence of upper gastrointestinal cancer [5]. Based on the effect of heavy metals on consumers, different organizations have proposed maximum permissible limits of the metals in edible vegetation, wastewater, and soils as shown in Table 1[6 - 10].

It has been reported that sewage effluents contain significant amounts of major plant nutrients and thus fertility levels of soil are increased under sewage irrigation of crops like cabbage, radish, cauliflower, spinach [11]. However, studies of crops (cabbage, radish, chandaliya ) irrigated with untreated sewage water revealed the presence of toxic metals like $\mathrm{Pb}, \mathrm{Cr}, \mathrm{Cd}, \mathrm{Ni}, \mathrm{Fe}, \mathrm{Co}, \mathrm{Zn}, \mathrm{Co}$, thereby reducing soil fertility and agricultural outputs [12]. In several parts of rural and urban Ethiopia, where effluent water is available, people cultivate vegetables with this type of water. This is true for areas around the towns of Aweday, Harar, Haramaya, as well as the vicinity of the main campus of Haramaya University (HU) in eastern Ethiopia.

The present study was undertaken to assess the extent of toxic trace heavy metal contamination in selected vegetables grown under irrigation with sewage water in various fields of Harari region near Harar, Aweday, and Haramaya towns of the Oromia National Regional State as well as the vegetable producing areas in the vicinity of the main campus of Haramaya University (HU). The study was necessary as a large number of people consume the produce and no research has been conducted to elucidate the extent of the problem in the region.

\section{MATERIALS AND METHODS}

\section{Experimental Sites}

Vegetable, soil, and effluent water samples were collected from different areas of East Hararghe Zone of the Oromia Regional State viz., Aweday town (9'21'36.75"N, $\left.42^{\circ} 02^{\prime} 44.01^{\prime \prime E}\right)$, Haramaya town $\left(9^{\circ} 23 ' 30.33^{\prime \prime} \mathrm{N}, 42^{\circ} 00^{\prime} 40.82^{\prime \prime} \mathrm{E}\right)$, the vicinity of Haramaya University (HU) $\left(9^{\circ} 25^{\prime} 05.69 " \mathrm{~N} ; 4^{\circ} 02^{\prime} 45.65^{\prime \prime E}\right)$, where toilet and laundry sewage from student dormitories flow into farmlands, and Harar town (9 18 '16.54"N, 


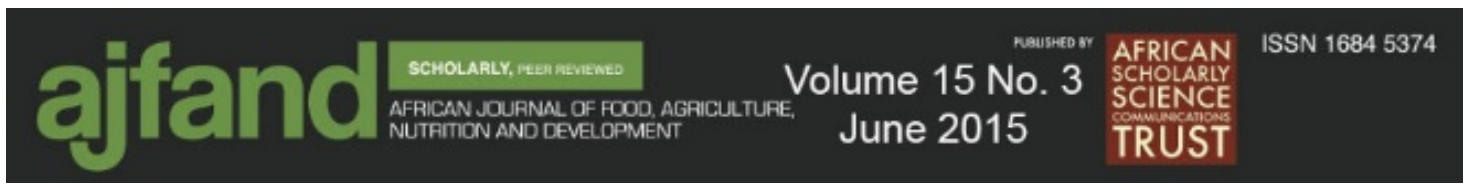

$\left.42^{\circ} 07^{\prime} 57.55^{\prime \prime E}\right)$. Analysing the heavy metals was conducted in the Chemistry and Soil Laboratory of Haramaya University.

\section{Chemicals, Reagents and Instruments}

All chemicals and reagents used were of analytical grade. $\mathrm{HNO}_{3}(69-72 \%$, Fine-Chem Mumbai-391780, India) and 70\% $\mathrm{HClO}_{4}$ (A.C.S. reagent, Aldrich, UK) were used for the digestion of the vegetable samples (cabbage, potato and khat). $\mathrm{HNO}_{3}(69-72 \%$, FineChem Mumbai-391780, India), $70 \% \mathrm{HClO}_{4}$ (A.C.S. reagent, Aldrich, UK) and $\mathrm{H}_{2} \mathrm{SO}_{4}$ (Fine-Chem Mumbai - 40002 India) were employed during digestion of the soil samples. $\mathrm{HNO}_{3}$ (69-72\%, Fine-Chem Mumbai-391780, India) and 36-37\% HCl (A.C.S. reagent, Aldrich, UK) were used in digestion of the effluent samples. Stock standard solutions $1000 \mathrm{mg} / \mathrm{L}$, containing 2\% $\mathrm{HNO}_{3}$, of the metals $\mathrm{Pb}$, Co, Cd and $\mathrm{Cr}$ (Buck Scientific PuroGraphicTM, USA) were used for preparation of the working solutions (which were immediately prepared before analysis) for calibration and in spiking experiments. The glassware and polyethylene containers used for analysis were washed with tap water, then soaked in $4 \mathrm{M} \mathrm{HNO}_{3}$ solution and rinsed several times with deionized water. Deionized water was used throughout the experiment for preparation and dilution of the sample solutions.

Air circulating oven (Genlab Limited, UK), electronic blending device (K-M20, IKAWERKE, Germany), ceramic mortar and pestle (Halden wanger, Germany), a digital analytical balance (Mettler Tolendo, Switzerland), stainless steel Auger, Kjeldahl block digester (Gallen kamp, England) were used. Flame atomic absorption spectrophotometer (Buck Scientific Model 210VGP AAS, East Norwalk, USA) with air-acetylene flame and deuterium background correction was used for the analysis of the target metals. The operational conditions of flame atomic absorption spectrometry (FAAS) are given in Table 2.

\section{Sample collection and preparation}

The effluent, soil, and vegetable samples were collected from January to April 2012. About $2 \mathrm{~kg}$ leaf samples of cabbage (Brassica oleraceae var. capitata), khat (Catha edulis Forsk), and potato (Solanum tuberosum L.) were collected, packed, labelled and transported to the laboratory. The samples were washed with tap water to eliminate soil and other dirt; the edible parts were separated from the other portions, rinsed with distilled deionized water, shredded (cabbage and khat leaves) and minced (potato tubers). The samples were air-dried in paper bags and then ground, sieved, homogenized, and heated in an oven at $105{ }^{\circ} \mathrm{C}$ to constant weights. The contents were cooled and placed in clean paper bags and stored in desiccators until digestion.

Soil samples (about $1 \mathrm{~kg}$ ) were collected from 0-15 cm depth in triplicates from the sites where the plants originated with an auger and placed in clean polyethylene bags. The composite soil samples were air-dried in a dry and dust-free place at room temperature $\left(25^{\circ} \mathrm{C}\right)$ for 5 days, followed by oven drying to constant weights. The samples were then ground with a mortar and pestle to pass through a 2-mm sieve and homogenized. The dried, sieved, and homogenized soil samples were stored in clean and dry containers till digestion. 
Effluent samples were collected from the four areas viz. Harar, Aweday, Haramaya town and the vicinity of Haramaya University from surfaces where effluents were directed to vegetable farms. The effluents were filled in to plastic bottles $(250 \mathrm{~mL})$, which were rinsed with the effluent water several times. The collected effluent water samples were taken to the laboratory and acidified with conc. $\mathrm{HNO}_{3}\left(5 \mathrm{~mL} \mathrm{~L}^{-1}\right)$ and stored in a clean area before analysis.

\section{Calibration procedure}

Calibration curves were prepared to determine the concentration of the heavy metals in the sample solutions. Intermediate standard solutions $(10 \mathrm{mg} / \mathrm{L})$ of each heavy metals were prepared from stock standard solutions containing $1,000 \mathrm{mg} \mathrm{L}^{-1}$ of $\mathrm{Co}, \mathrm{Cd}, \mathrm{Cr}$ and $\mathrm{Pb}$. Appropriate working standards were prepared for each of the metal solution by serial dilution of the intermediate solutions using deionized water. Potassium chloride solution was added as an ionization suppressor for determining the concentration of Cr. Analytical wavelengths, colour of the flame and slit width were adjusted according to the instrument operation manual to attain its better sensitivity and working standards were then aspirated one after the other into the flame atomic absorption spectrometry and their absorbance was recorded. Calibration curves were plotted with four points for each of the trace heavy metals standard using absorbance against concentrations $(\mathrm{mg} / \mathrm{L})$. Immediately after calibration using the standard solutions, the sample solutions were aspirated into the FAAS instrument and direct reading of the metal concentrations was recorded.

\section{Digestion of the plant samples}

To obtain a clear sample solution that is suitable for the analysis using flame atomic absorption spectrometry, different digestion procedures for the plant samples (cabbage, potato, and khat) were assessed using concentrated $\mathrm{HNO}_{3}$ and $\mathrm{HClO}_{4}$ acid mixtures by varying the volume of the acid mixture, digestion time, and temperature of the method. Optimized procedure was selected based on usage of lesser reagent volume, shorter digestion time, and reasonably mild temperature for obtaining clear solutions of the resulting digests. Among the different digestion procedures tested, digesting a plant sample weighing $0.5 \mathrm{~g}$ with $5 \mathrm{~mL}$ of $3: 2(\mathrm{v} / \mathrm{v})$ mixture of concentrated $\mathrm{HNO}_{3}$ and concentrated $\mathrm{HClO}_{4}$ heated at $250{ }^{\circ} \mathrm{C}$ for 55 minutes on a Kjeldahl digestion block was chosen. After the digestion was completed, the digest was cooled and filtered into $50 \mathrm{~mL}$ volumetric flasks using Whatman no. 41 filter paper to remove any suspended and turbid matter. After rinsing, the solutions were diluted to the mark with deionized water. The digestion was made in triplicates for each of the vegetable samples collected from the four sampling sites. Digestion of a reagent blank was performed along with the vegetable samples keeping all digestion parameters the same. All the digested and diluted samples were stored in a refrigerator at $4^{\circ} \mathrm{C}$ until analysis.

\section{Digestion of the soil samples}

A digestion method reported by Allen et al .[13] was used for the digestion of the soil samples after making a slight modification on the procedure to obtain clear solutions of the digest. Accordingly, a soil sample weighing $1 \mathrm{~g}$ was digested on Kjeldahl digestion block by adding $7 \mathrm{~mL}$ of tri-acid mixture $\left(\mathrm{HNO}_{3}, \mathrm{H}_{2} \mathrm{SO}_{4}\right.$, and $\mathrm{HClO}_{4}$ in 5:1:1 $(\mathrm{v} / \mathrm{v} / \mathrm{v})$ ratio) at $100{ }^{\circ} \mathrm{C}$ for $40 \mathrm{~min}$ and then at $160{ }^{\circ} \mathrm{C}$ for $50 \mathrm{~min}$ to obtain a transparent solution 


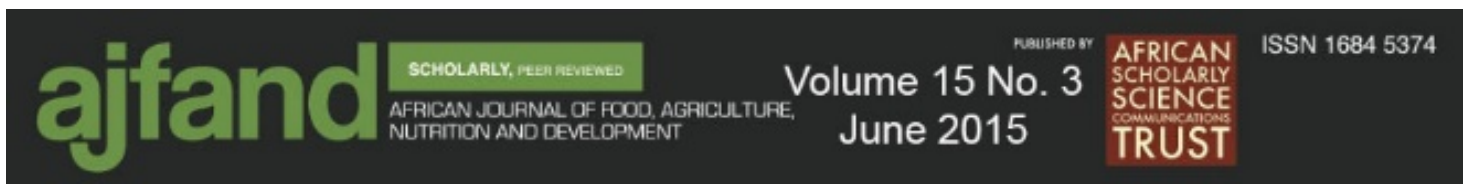

of the digest. The digested sample was filtered using Whatman no. 41 filter paper after cooling, and the filtrate was finally made up to $100 \mathrm{~mL}$ with deionized water.

\section{Digestion of the effluent samples}

United State Environmental Protection Agency (US EPA) 3005A [14] method was used for digesting the effluent water samples used for irrigating the vegetables. A $50 \mathrm{~mL}$ aliquot of well mixed effluent samples was digested in a beaker covered with a watch glass by adding $1 \mathrm{~mL}$ of concentrated $\mathrm{HNO}_{3}$ and $2.5 \mathrm{~mL}$ of concentrated $\mathrm{HCl}$ and heated on a hot plate at $90{ }^{\circ} \mathrm{C}$ until the volume was reduced to about $15 \mathrm{~mL}$. Then the beaker was removed and cooled. The solution was filtered and finally diluted to $100 \mathrm{~mL}$ with distilled-deionized water. The level of heavy metals in the filtrate was determined by FAAS.

\section{Method Detection Limit}

Nine replicate blank samples were digested following the same procedures utilised for digesting the vegetable, soil, and effluent samples. Each blank was assayed for its metal contents ( $\mathrm{Cr}, \mathrm{Co}, \mathrm{Cd}$ and $\mathrm{Pb}$ ) by FAAS. The standard deviations (SD) of the nine replicate blanks were calculated to determine the method detection limit (MDL) and limit of quantification (LOQ). Method detection limit (MDL) was calculated as three times the standard deviations (MDL $=3 \mathrm{SD}$ ) and LOQ was calculated as ten times the standard deviation $(\mathrm{LOQ}=10 \mathrm{SD})[15]$. The $\mathrm{MDL}$ values obtained were compared with the instrument detection limit (IDL) and found to have greater values in all cases (Table 3).

\section{Analytical method validation}

Efficiency of the optimized procedure used for digesting the vegetable samples, soil, and effluent samples were checked by spiking the pre-treated vegetable, soil and effluent water samples with standard solutions of each metal having a known concentration. The spiked vegetables, soil, and effluent samples were digested following the same procedure employed in the digestion of the respective samples. Accordingly, a $0.5 \mathrm{~g}$ of cabbage sample was spiked with $5 \mathrm{mg} \mathrm{kg}^{-1} \mathrm{Cr}$ and $\mathrm{Pb}$ and $1 \mathrm{mg} \mathrm{kg}^{-1} \mathrm{Cd}$ and $\mathrm{Co}$. The same amount $(0.5 \mathrm{~g})$ of potato and khat leaf samples were spiked with $5 \mathrm{mg} \mathrm{kg}^{-1} \mathrm{Cr}$, Co, and $\mathrm{Pb}$, and 1 $\mathrm{mg} \mathrm{kg}^{-1} \mathrm{Cd}$. For the soil sample, $1 \mathrm{~g}$ was spiked with $10 \mathrm{mg} \mathrm{kg}^{-1} \mathrm{Cr}$ and $\mathrm{Pb}, 5 \mathrm{mg} \mathrm{kg}^{-1} \mathrm{Co}$ and $1 \mathrm{mg} \mathrm{kg}^{-1} \mathrm{Cd}$. However, the effluent water sample (50 mL) was spiked with $0.5 \mathrm{mg}$ $\mathrm{kg}^{-1} \mathrm{Cr}$ and $\mathrm{Cd}$ and $1 \mathrm{mg} \mathrm{kg}^{-1} \mathrm{Co}$ and $\mathrm{Pb}$. For the vegetables, effluent, and soil samples, the recovery was performed in triplicates.

\section{Transfer factor (TF)}

Transfer factor (TF) was calculated to understand the risk associated with wastewater irrigation and consequent heavy metal accumulation in the edible portions of the test vegetables following a standard procedure [16].

TF

Concentration of metal in the edible part

$=\overline{\text { Concentration of chemical element in soil under irrigation with wastewater }}$ 


\section{Statistical Analysis}

Analysis of variance (ANOVA) was used to test the level of significance at $\alpha=0.05$ [17]. Means were separated using the least significant difference test at 5\% level of significance. A correlation test was carried out between the investigated metals for the vegetable materials and among metals detected in the soil and vegetables to associate the distribution of metals in the soil samples and their availability and accumulation in the vegetables at $\alpha=0.05$.

\section{RESULTS}

\section{Evaluation of the analytical method}

In this study, the method validation was made by a spiking experiment in which known quantities of the metal standard solution were added to the samples to be studied. Percentage recovery values for individual analysis for soil, effluent, and vegetable samples are presented in Table 4. The percentage recovery values of the metals for soil, effluent, and vegetable samples were found to be within the range of 91.0-98.3\%, 92.0 $102 \%$, and $89.0-101 \%$, respectively. These ranges are within the acceptable range [18] which confirmed the validity of the method utilized in the current study.

\section{Metals in the effluent samples}

The data presented in Figure 1 show that high concentrations ( $\mathrm{mg} \mathrm{kg}^{-1}$ ) of the toxic heavy metals were found in the effluent samples from some of the sites. The concentration of $\mathrm{Cr}$ in the effluent was found to be the lowest $\left(0.17 \mathrm{mg} \mathrm{kg}^{-1}\right)$ in the samples collected from Haramaya town and the highest $\left(0.26 \mathrm{mg} \mathrm{kg}^{-1}\right)$ in the samples collected from both Harar and Haramaya University (HU). The concentration of the same metal was found to be $0.21 \mathrm{mg} \mathrm{kg}^{-1}$ in the effluent collected from Aweday site. The concentration of Cd in the effluents varied from $0.04 \mathrm{mg} \mathrm{kg}^{-1}$ for the sample collected from Haramaya site to 0.05 mg kg-1 for the sample collected from Aweday, $0.06 \mathrm{mg} \mathrm{kg}^{-1}$ for the sample collected from Harar town. The highest concentration of the metal $\left(0.08 \mathrm{mg} \mathrm{kg}^{-1}\right)$ was observed in the effluent sampled from $\mathrm{HU}$ site. The concentration of $\mathrm{Co}$ in the effluent ranged from $0.57 \mathrm{mg} \mathrm{kg}^{-1}$ from Harar and Haramaya towns to $0.71 \mathrm{mg} \mathrm{kg}^{-1}$ from HU and $1.02 \mathrm{mg} \mathrm{kg}$ ${ }^{1}$ from Aweday town. However, the highest concentration in the effluent sample was found to be that of $\mathrm{Pb}$, which ranged from $0.82 \mathrm{mg} \mathrm{kg}^{-1}$ for the sample collected from Haramaya town to $1.12 \mathrm{mg} \mathrm{kg}^{-1}$ for the sample collected from Harar town, and $1.72 \mathrm{mg}$ $\mathrm{kg}^{-1}$ for the sample obtained from Aweday town. The highest concentration (2.52 mg kg ${ }^{1}$ ) of this heavy metal was detected in the effluent collected from the vicinity of Haramaya University. The heavy metals with the next highest concentration in the effluents were $\mathrm{Co}$ and $\mathrm{Cr}$. The concentration of $\mathrm{Cd}$ was found to be the lowest in the effluent waters collected from all sites.

\section{Metals in the soil samples}

The concentrations of heavy metals ( $\mathrm{Cr}, \mathrm{Co}, \mathrm{Cd}$, and $\mathrm{Pb}$ ) are shown in Figure 2. The concentrations of the metals analysed varied in the soil samples. High Cr concentration (41.45 mg kg-1) was observed for the HU site and the least concentration (25.71 $\mathrm{mg} \mathrm{kg}^{-1}$ ) was recorded for the Aweday site. However, $\mathrm{Cr}$ concentration in soils of Haramaya and Harar sites were $29.52 \mathrm{mg} \mathrm{kg}^{-1}$ and $37.62 \mathrm{mg} \mathrm{kg}^{-1}$, respectively. The concentration of Cd in the soil samples was found to be $0.79,1.38,1.43$ and $2.56 \mathrm{mg} \mathrm{kg}^{-1}$ for Haramaya, Harar, 


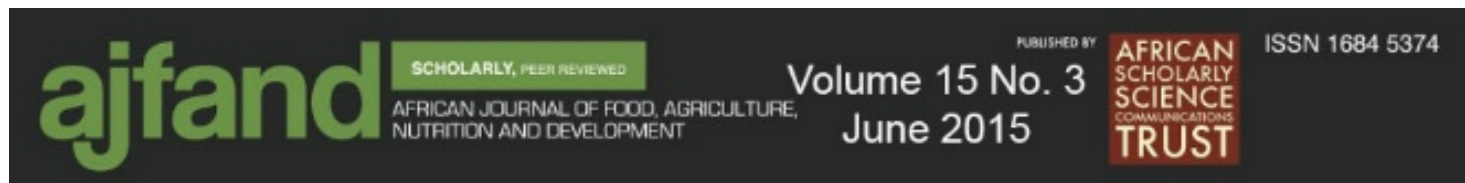

Aweday and HU sites, respectively. Similarly, the soil from which the vegetables originated revealed high Co concentration (23.59 $\mathrm{mg} \mathrm{kg}^{-1}$ ) from the HU site. This was closely followed by the Co concentration collected from Harar and Aweday sites, which amounted to $17.69 \mathrm{mg} \mathrm{kg}^{-1}$ and $20.65 \mathrm{mg} \mathrm{kg}^{-1}$, respectively. The lowest Co concentration (17.69 mg kg-1) was observed for the Haramaya site. The soil sample from HU site contained high Pb concentration (47.29 $\mathrm{mg} \mathrm{kg}^{-1}$ ) followed by soil from Aweday site (31.25 $\left.\mathrm{mg} \mathrm{kg}^{-1}\right)$. The lowest and comparable $\mathrm{Pb}$ concentration $\left(26.04 \mathrm{mg} \mathrm{kg}^{-1}\right)$ was recorded in soil samples of Haramaya and Harar towns. Among the targeted heavy metal analytes, $\mathrm{Cr}$ was found to be the highest in concentration followed by $\mathrm{Pb}$ and $\mathrm{Co}$. The concentration of Cd was found to be the lowest in the soil samples from all the sampling sites.

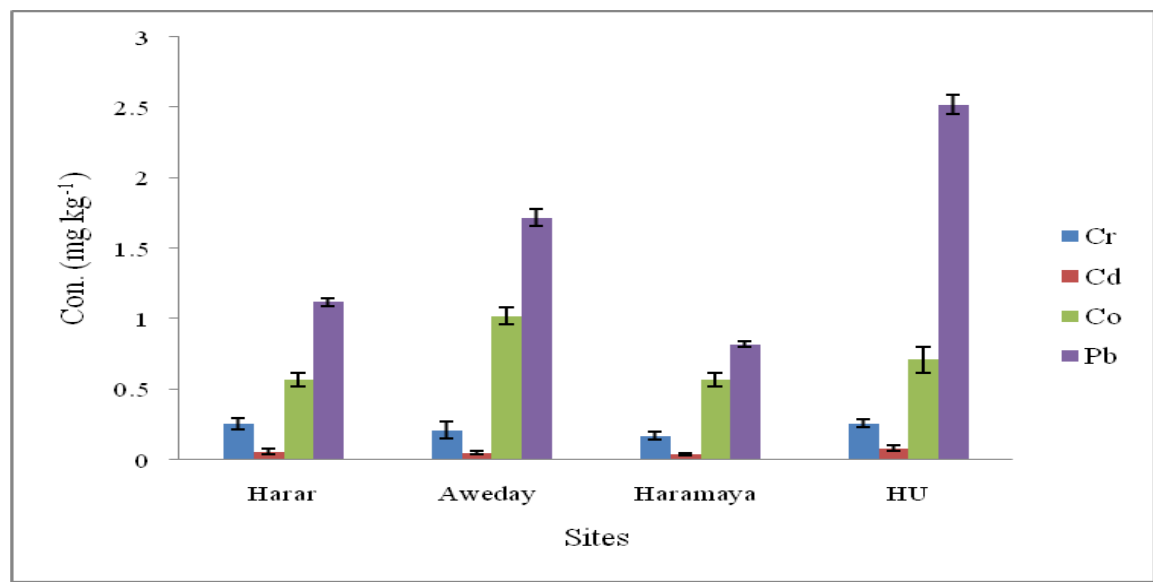

Figure1: Concentrations of heavy metals in the effluent samples HU = the vicinity of Haramaya University

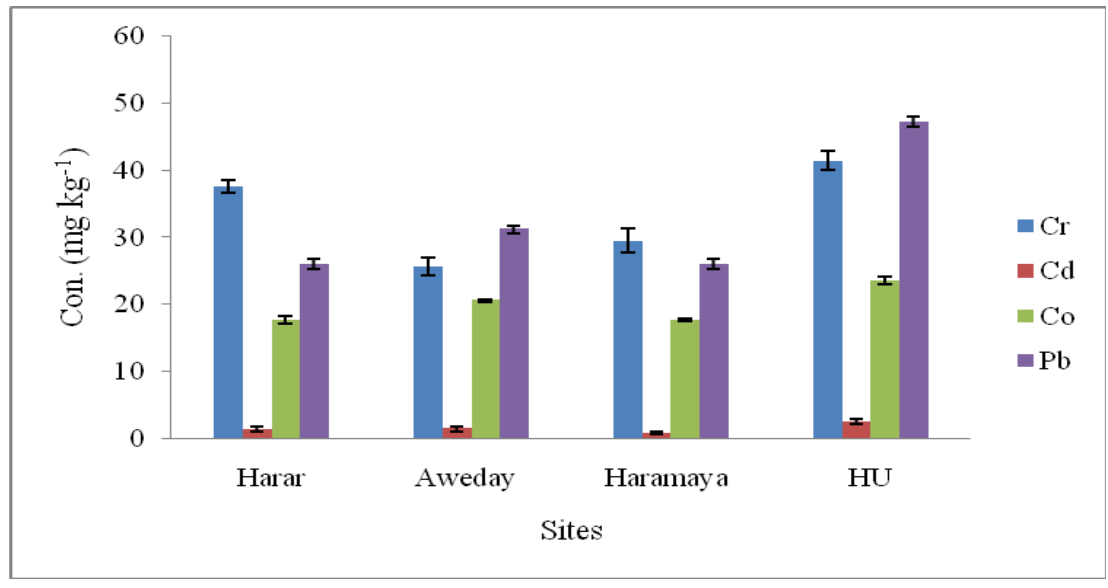

Figure 2: Concentrations of heavy metals in the soil samples of the plant origins $\mathrm{HU}=$ the vicinity of Haramaya University

\section{Metals in the vegetables}

The concentrations of the metals $(\mathrm{Cr}, \mathrm{Co}, \mathrm{Cd}$ and $\mathrm{Pb})$ in the investigated vegetables are given in Figures 3-5 for the cabbage, potato, and khat samples, respectively. The metal concentrations ( $\mathrm{mg} \mathrm{kg}^{-1}$ ) in cabbage samples were found to be $<$ MDL-17.13, 5.72-9.72, 


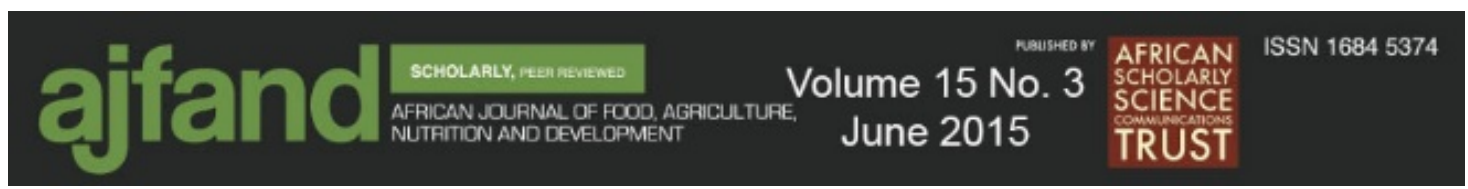

1.15-2.46 and 5.48-11.95 for $\mathrm{Cr}$, Co, $\mathrm{Cd}$ and $\mathrm{Pb}$, respectively (Figure 3). The concentrations $\left(\mathrm{mg} \mathrm{kg}^{-1}\right)$ of heavy metals in potato samples from Aweday and the vicinity of HU sites ranged from 11.96-14.21, 5.15 -8.72, 1.22-1.46, and 5.43-7.78 for $\mathrm{Cr}, \mathrm{Co}, \mathrm{Cd}$ and $\mathrm{Pb}$, respectively (Figure 4). The metal concentrations $\left(\mathrm{mg} \mathrm{kg}^{-1}\right)$ in khat samples were found to be 9.04-14.54, <MDL-8.87, 0.38-3.22, and 4.49-10.95 for Cr, Co, Cd and Pb, respectively (Figure 5).

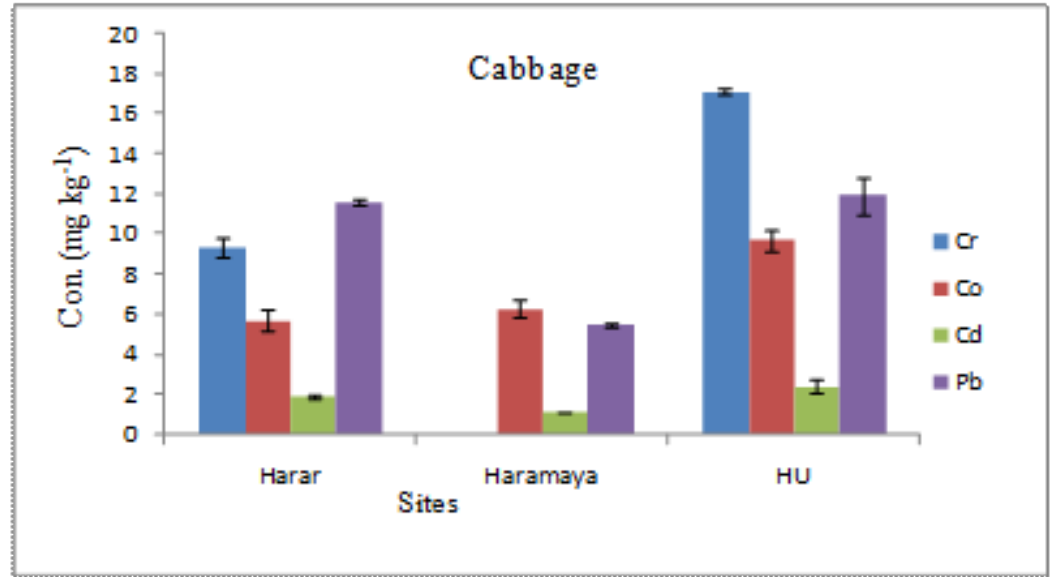

Figure 3: Concentrations of heavy metals in cabbage $\mathrm{HU}=$ the vicinity of Haramaya University

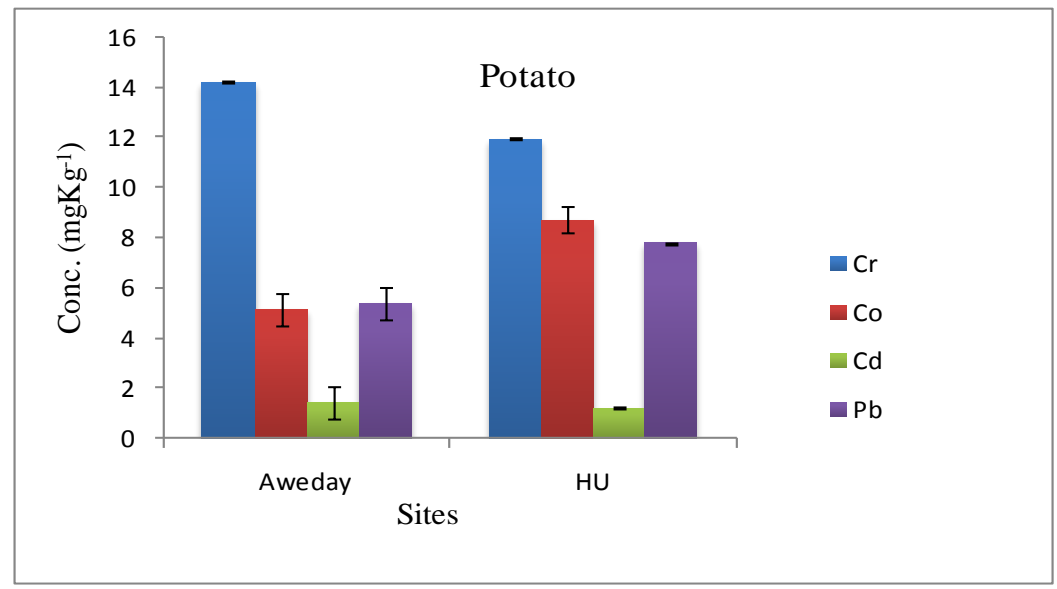

Figure 4: Concentrations of the heavy metals in Potato $\mathrm{HU}=$ the vicinity of Haramaya University 

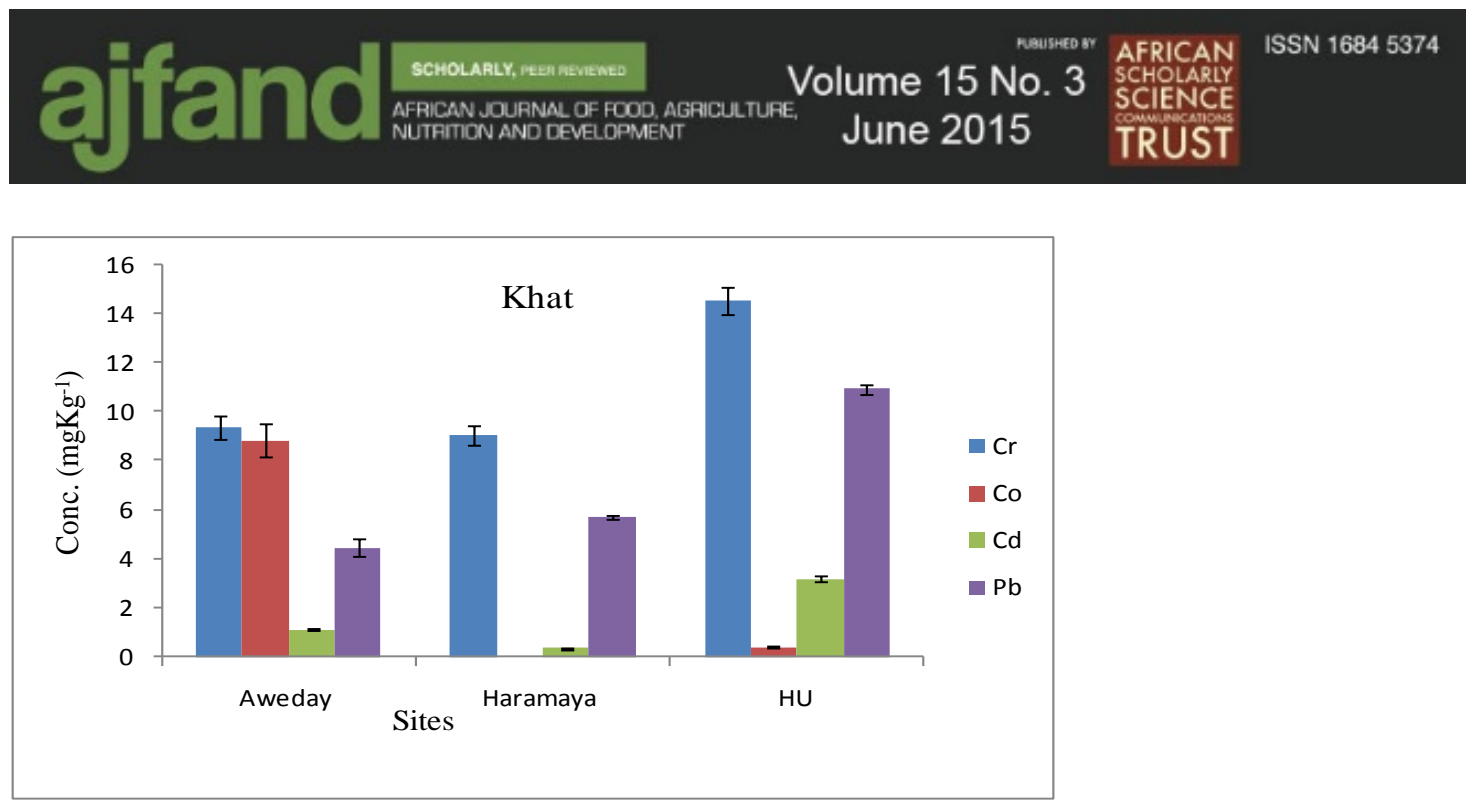

Figure 5: Concentrations of the heavy metals in Khat $\mathrm{HU}=$ the vicinity of Haramaya University

Comparison of metal concentrations in the vegetables with other edible and medicinal plants

The levels of metal concentration in the vegetables (cabbage, potato and khat) were compared with other edible and medicinal plants reported in various parts of the world as summarized in Table 5. Based on the comparison, the results of the present study are in agreement with most of the reported values.

\section{Transfer Factor (TF)}

Among the different metals, Cd showed the maximum transfer factor value (Table 6), which ranged from 0.48 (khat from Haramaya) to 1.46 (cabbage from Haramaya) and it was minimum for Co, ranging from 0.02 (khat from HU) to 0.43 (khat from Aweday). The transfer factor for $\mathrm{Cr}$ and $\mathrm{Pb}$ ranged from 0.25 (cabbage from Harar) to 0.55 (potato from Aweday) and 0.14 (khat from Aweday) to 0.45 (cabbage from Harar). The transfer factors of heavy metals for the different vegetables in the current study were compared with similar and other edible plants (Table 7).

\section{Statistical Evaluation}

Pair-wise statistical analyses of the results were made to verify whether there were significant differences in concentrations of the heavy metals in the effluent water, soil, and vegetable samples assayed with the sampling sites. For the present study, the significance of variation within sample and between samples has been studied using a one-way ANOVA [19]. At 95\% confidence level, for the effluent samples, no significant difference $(\mathrm{P}>0.05)$ was observed for $\mathrm{Cr}$ (except for those from Harar/Haramaya and Haramaya/HU), Cd (except for the samples from Haramaya/HU) and Co (except for the samples from Harar/Aweday and Aweday/HU). However, significant differences (P < 0.05) were observed for $\mathrm{Pb}$ between the samples from the various sampling areas. For the case of soil samples, significant differences $(\mathrm{P}<0.05)$ were observed for most of the investigated metals except $\mathrm{Cd}$ (for the samples from Harar/Aweday, Harar/Haramaya and Aweday/Haramaya), and $\mathrm{Co}$ and $\mathrm{Pb}$ (for those from Harar/Haramaya). For the cabbage samples, significant differences $(\mathrm{P}<0.05)$ were observed for $\mathrm{Cr}$, Cd (except for the samples from Harar/HU) and Co (except for the samples from Harar/Haramaya) and 


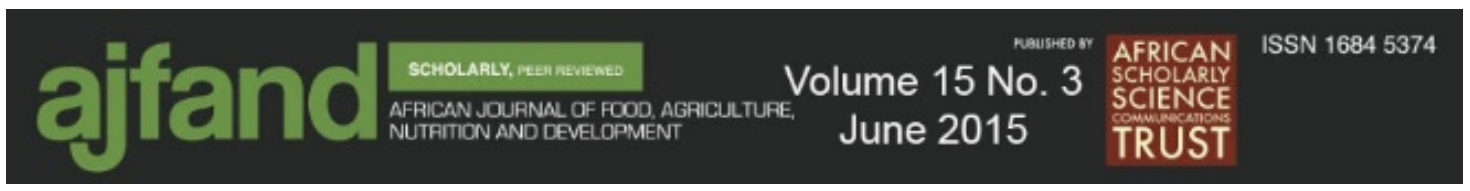

$\mathrm{Pb}$ (except for those from Harar/HU). In the case of potato samples, significant differences $(\mathrm{P}<0.05$ ) were observed for $\mathrm{Cr}, \mathrm{Cd}$, Co and $\mathrm{Pb}$ for different sampling sites. Similarly, all metals had significant variations $(\mathrm{P}<0.05)$ for khat with the sampling sites except for $\mathrm{Cr}$ which did not vary significantly $(\mathrm{P}>0.05)$ for the samples from Aweday/Haramaya.

\section{DISCUSSION}

\section{Levels of metals in the effluent samples}

The effluent analysis revealed significant differences in the concentrations of heavy metals in the samples collected from the various sampling areas. The differences may be attributed to the fact that the contaminating analytes depended on sources of the wastewater discharged to the irrigation water. Heavy metals in the sewage water are associated with small scale industries such as colouring, electroplating, metal surface treatments, fabric printing, battery and paints, releasing $\mathrm{Cd}, \mathrm{Co}, \mathrm{Cr}, \mathrm{Pb}, \mathrm{Zn}, \mathrm{Ni}$ and other heavy metals into water channels, which are accessed for irrigation [20].

The concentrations of $\mathrm{Cd}$ and Co detected in the effluent waters exceeded the safe limits set by international organizations viz., [6, 7, 9]. The concentration of $\mathrm{Pb}$ in all the effluent water samples was found to be under the safe limit [7], but above the limit when compared with other international organizations ([6, 9]). However, Cr exceeded the safe limit according to [10], but was below the limit according to [6, 9]. The results obtained show that the effluent samples are profoundly contaminated with these heavy metals. Therefore, attention should be focussed on regular monitoring and control of wastewater used for irrigation.

\section{Levels of metals in the soil samples}

For the soil samples, the concentration of heavy metals considered in the current study viz., $\mathrm{Cd}, \mathrm{Cr}, \mathrm{Co}$ and $\mathrm{Pb}$ were found to be below the safe limits set by different organizations ([6, 8]). The critical level of Cd in the soil for plant growth is $3 \mathrm{mg} \mathrm{Cd} / \mathrm{kg}$ soil [21]. However, the concentration of Cd was found to be high and approaching the safe limits in the soil samples collected from HU site according to the standard sets ([6, 8]). The concentration of $\mathrm{Cd}$ in the soil may be increased due to the application of sludge [21]. Cadmium (Cd) is also added to the soil in small amounts in phosphate fertilizers [22]. The relatively higher concentration of $\mathrm{Cd}$ in soils sampled from the vicinity of Haramaya University may be attributed to the higher sewage sludge emanating from the residences of staff and students as well as the higher use of phosphate fertilizers in the research and nearby farms in the area. This indicates that the level of cadmium in the soil needs to be managed.

\section{Levels of metals in the vegetables}

Except for cabbage samples collected from Haramaya site (<MDL), the concentrations of $\mathrm{Cr}$ detected in all of the vegetables analysed in this study were higher than the limit levels in food by FAO/WHO guidelines [23]. The concentration of Cr was observed to be the highest for cabbage samples collected from HU site and it was below method detection limit in cabbage samples from Haramaya site. However, the amounts in all samples were below the permissible limit set by Indian standards [6]. Among the 


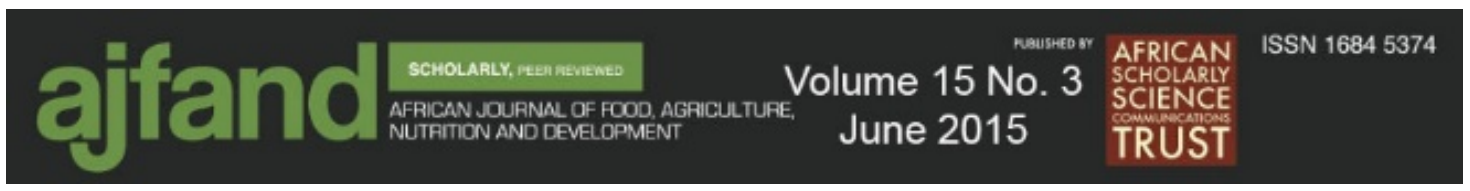

investigated vegetables, cabbage was found to be more Cr-loaded than potato and khat. Higher concentration of this heavy metal was obtained in vegetables from HU site which might be due to sewage sludge discharged to the environment from laboratories as well as from toilets and laundries of student dormitories and staff residences of the University.

The concentrations of Co detected in all of the vegetables analysed, in this study, were far lower than the stipulated permissible levels in food by FAO/WHO guidelines [10]. Based on these results, it can be summarized that the vegetables are safe to consumers in terms of Co. However, amongst the investigated vegetables, cabbage was found to be more cobalt-loaded than potato and khat, and high concentration of the heavy metal was obtained from vegetable samples collected from the vicinity of Haramaya University.

All samples of the current study contained Cd concentration above the maximum permissible limit set by different organization, which is $0.1 \mathrm{mg} \mathrm{kg}^{-1}$ [10] and $0.2 \mathrm{mg} \mathrm{kg}^{-1}$ [7]. Among the sampling sites, the samples from the HU site contained higher Cd concentration which might be attributed to the sewage sludge discharge from the University's laboratories, student dormitories, garage and cafeterias. Cadmium is a toxic metal and can cause serious health problems. Recently, attention has been focused on its availability in water, soil, milk, dietary products, medicinal plants, and herbal drugs [24]. The most common sources for $\mathrm{Cd}$ in soil and plants are phosphate fertilizers, non-ferrous smelters, lead and zinc mines, sewage sludge application and combustion of fossil fuels [25]. Leafy vegetables (khat and cabbage) contained the highest levels of Cd which shows higher accumulation of this metal in the aerial parts of the plants than the roots. It has been reported that $\mathrm{Cd}$ is a highly mobile metal, easily absorbed by the plants through root surface and moves to wood tissue and transfers to upper parts of plants [26].

The vegetable samples also contained $\mathrm{Pb}$ above the maximum permissible limit sets ([6, $7,10]$ ). Hence, the vegetables collected from the four sampling sites (Aweday, Harar, Haramaya, and $\mathrm{HU}$ ) are not safe to consume in terms of $\mathrm{Pb}$ content. Cabbage accumulated the highest amount of $\mathrm{Pb}$ followed by khat and potato samples. The three samples collected from $\mathrm{HU}$ site accumulated higher $\mathrm{Pb}$ than samples from the other sites which might be due to the effluents from laboratories and toilets from the University. Lead is a toxic element that can be harmful to plants, although plants usually show the ability to accumulate large amounts of $\mathrm{Pb}$ without visible changes in their appearance or yield. In many plants, $\mathrm{Pb}$ accumulation can exceed several hundred times than the threshold of maximum level permissible for humans [27]. On the whole, all vegetables that were studied in this study were contaminated by $\mathrm{Pb}$ and are bound to be unsafe for human consumption.

\section{Transfer Factor (TF)}

Variations in transfer factor among the different vegetables may be attributed to differences in the concentration of metals in the soil and differences in element uptake by different vegetables [28]. Among all the vegetables, transfer factor of Cd was highest for assayed vegetables from the four sampling sites, which showed that $\mathrm{Cd}$ is more mobile than the other metals. Consistent with this suggestion, it was reported that $\mathrm{Cd}$ was retained less strongly by the soil and hence it is more mobile than other metals [29]. Transfer factor of 0.1 indicates that the plant is excluding the element from its tissues. 


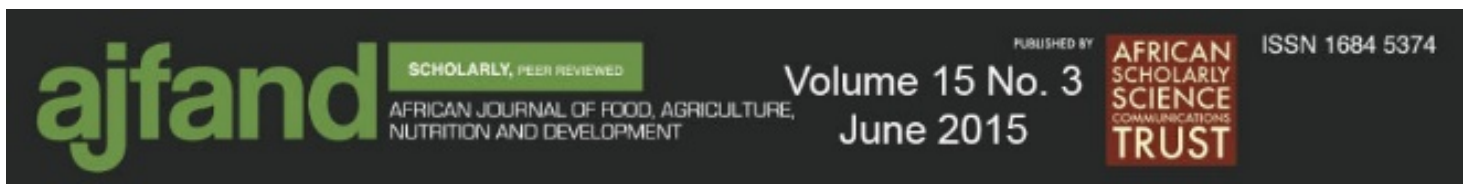

The greater the transfer coefficient value than 0.50 , the greater will be the chances of vegetables for metal contamination by anthropogenic activities [30]. Hence, most of the metals might be affected by anthropogenic activities based on the transfer factor calculated in the current study. The transfer factor does not present the risk associated with the metals in any form. Therefore, the degree of toxicity of heavy metals to human beings depends upon their daily intake [28]. When compared with a previous study Tyokumbur \& Okorie [31], Jolly et al.[32] and Gebrekidan et al.[33], the current study showed a higher ease of transfer factor that can be attributed to differences in location and samples [31], and anthropogenic activities in the area.

\section{CONCLUSIONS}

The results of this study demonstrated that $\mathrm{Cr}$ was found in the highest concentration in the vegetables studied from among the investigated toxic heavy metals. The range of metals in the vegetables ranged from $<$ MDL-17.13, 1.22-14.21, and $<$ MDL-14.54 in cabbage, potato and khat, respectively. The respective soil samples contained higher concentrations of all assayed metals than the corresponding plant materials except for the case of $\mathrm{Cd}$ in some samples (cabbage from Harar and Haramaya, potato from Aweday and khat from Haramaya University) in which higher concentrations of the metal were detected in the plant samples than in the corresponding soil samples. In general, the results revealed that high concentrations of the toxic heavy metals were found in the vegetable samples, which are above the international safe limits. This reveals that consuming the vegetables produced in these areas poses health risks to humans. Therefore, people should be advised against consuming vegetables cultivated through irrigation with wastewater. It is also important to make farmers in the area aware of the danger of using wastewater for growing crops, and alternative sources of clean water should be sought for farmers to irrigate their crops during the dry seasons.

\section{ACKNOWLEDGEMENTS}

The authors are grateful to Research and Extension Office of Haramaya University for providing the financial support for the study and for facilitating transport and logistics during sample collection. We would also like to thank the Department of Chemistry and Laboratory Management Office of the University for providing laboratory facilities for analysing the effluent, vegetable, and soil samples. 


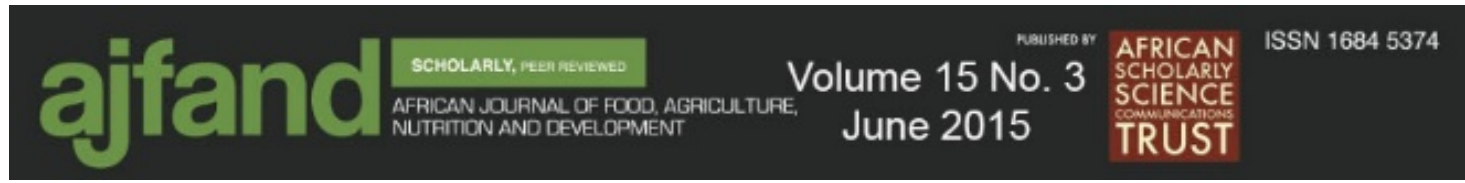

Table 1: Guideline for safe limits of heavy metals in soil, water, and edible plants

\begin{tabular}{llllll}
\hline Sample & Standards & \multicolumn{4}{c}{ Metals } \\
\cline { 3 - 6 } & & Cr & Co & Cd & Pb \\
\hline Soil (mg/kg) & Indian [6] & - & - & $3-6$ & $250-500$ \\
& WHO/FAO [7] & - & - & - & - \\
& European Union [8] & 150 & - & 3.0 & 300 \\
\hline Water (mg/L) & Indian [6] & 0.05 & - & 0.01 & 0.10 \\
& European Union [8] & - & - & - & - \\
& FAO [9] & 0.10 & 0.05 & 0.01 & 5.0 \\
\hline Plant (mg/kg) & Indian [6] & 20.0 & - & 1.5 & 2.5 \\
& WHO/FAO [7] & - & - & 0.2 & 5.0 \\
& FAO/WHO [10] & - & 50.00 & 0.10 & 0.30 \\
\hline
\end{tabular}

Table 2: Flame atomic absorption spectrometry instrument operational parameters

\begin{tabular}{cccc}
\hline Metal & Wavelength $(\mathrm{nm})$ & Slit width (nm) & Lamp current (mA) \\
\hline $\mathrm{Cr}$ & 357.9 & 0.7 & 2.0 \\
$\mathrm{Co}$ & 240.7 & 0.2 & 4.5 \\
$\mathrm{~Pb}$ & 283.3 & 0.7 & 2.0 \\
$\mathrm{Cd}$ & 228.9 & 0.7 & 2.0 \\
\hline
\end{tabular}




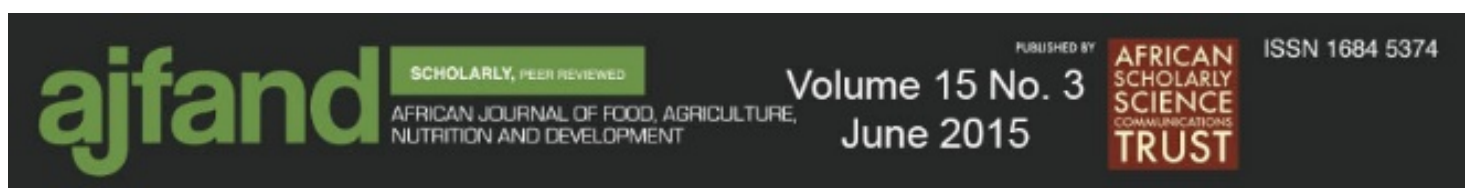

Table 3: MDL and LOQ for the assayed samples

\begin{tabular}{lllll}
\hline Sample & Metal & MDL & LOQ & IDL \\
\hline \multirow{3}{*}{ Effluent } & Chromium & 0.175 & 0.584 & 0.050 \\
& Cadmium & 0.028 & 0.094 & 0.005 \\
& Cobalt & 0.146 & 0.487 & 0.050 \\
& Lead & 0.304 & 1.014 & 0.100 \\
\hline \multirow{3}{*}{ Soil } & Chromium & 0.277 & 0.922 & 0.050 \\
& Cadmium & 0.037 & 0.123 & 0.005 \\
& Cobalt & 0.137 & 0.457 & 0.050 \\
& Lead & 0.513 & 0.712 & 0.100 \\
\hline \multirow{2}{*}{ Vegetables } & Chromium & 0.175 & 0.584 & 0.050 \\
& Cadmium & 0.032 & 0.107 & 0.005 \\
& Cobalt & 0.139 & 0.463 & 0.050 \\
& Lead & 0.362 & 1.207 & 0.100 \\
\hline
\end{tabular}

Table 4: Percentage recovery values ( $\overline{\mathbf{x}} \pm S D, n=3$ ) of vegetables, effluent water and soil samples

\begin{tabular}{|c|c|c|c|c|c|}
\hline \multicolumn{2}{|c|}{ Samples } & \multicolumn{4}{|c|}{ Metals } \\
\hline \multirow{5}{*}{ cabbage } & & $\mathrm{Cr}$ & $\mathrm{Cd}$ & Co & $\mathrm{Pb}$ \\
\hline & CIS $^{\mathrm{a}}$ & 9.4 & 1.9 & 5.7 & 12 \\
\hline & $\mathrm{AA}^{\mathrm{b}}$ & 5 & 1 & 1 & 5 \\
\hline & $\mathrm{AR}^{\mathrm{c}}$ & 4. $8 \pm 0.23$ & $0.96 \pm 0.04$ & $1.1 \pm 0.11$ & $4.9 \pm 0.08$ \\
\hline & $\mathrm{R}^{\mathrm{d}}(\%)$ & 95.6 & 96.0 & 106 & 98.2 \\
\hline \multirow{4}{*}{ potato } & CIS $^{\mathrm{a}}$ & 14 & 1.5 & 8.7 & 7.8 \\
\hline & $\mathrm{AA}^{\mathrm{b}}$ & 5 & 1 & 5 & 5 \\
\hline & $\mathrm{AR}^{\mathrm{c}}$ & $5.1 \pm 0.06$ & $0.89 \pm 0.05$ & $4.9 \pm 0.21$ & $4.8 \pm 0.12$ \\
\hline & $\mathrm{R}^{\mathrm{d}}(\%)$ & 101 & 89.0 & 97.2 & 96.6 \\
\hline \multirow{4}{*}{ khat } & CIS $^{\mathrm{a}}$ & 9 & 3.2 & 8.9 & 11 \\
\hline & $\mathrm{AA}^{\mathrm{b}}$ & 5 & 1 & 5 & 5 \\
\hline & $\mathrm{AR}^{\mathrm{c}}$ & $4.7 \pm 0.1$ & $0.9 \pm 0.07$ & $4.7 \pm 0.06$ & $4.9 \pm 0.02$ \\
\hline & $\mathrm{R}^{\mathrm{d}}(\%)$ & 94.6 & 94.0 & 94.2 & 99.4 \\
\hline \multirow{4}{*}{ effluent } & CIS $^{\mathrm{a}}$ & 0.3 & 0.06 & 1.0 & 2.5 \\
\hline & $\mathrm{AA}^{\mathrm{b}}$ & 0.5 & 0.5 & 1 & 1 \\
\hline & $\mathrm{AR}^{\mathrm{c}}$ & $0.5 \pm 0.03$ & $0.5 \pm 0.01$ & $0.97 \pm 0.02$ & $0.9 \pm 0.05$ \\
\hline & $\mathrm{R}^{\mathrm{d}}(\%)$ & 92.0 & 102 & 97.0 & 93.0 \\
\hline \multirow{4}{*}{ soil } & CIS $^{a}$ & 37.6 & 1.4 & 18 & 26 \\
\hline & $\mathrm{AA}^{\mathrm{b}}$ & 10 & 1 & 5 & 10 \\
\hline & $\mathrm{AR}^{\mathrm{c}}$ & $9.8 \pm 0.13$ & $0.9 \pm 0.09$ & $4.9 \pm 0.03$ & $9.2 \pm 0.07$ \\
\hline & $\mathrm{R}^{\mathrm{d}}(\%)$ & 98.3 & 91.0 & 97.6 & 92.1 \\
\hline
\end{tabular}




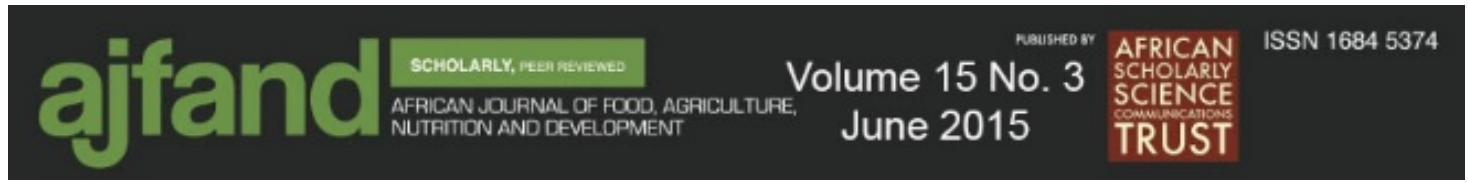

Table 5: Comparison of metal concentration $(\mathrm{mg} / \mathrm{kg})$ in the vegetables with other edible and medicinal plants from the literature

\begin{tabular}{|c|c|c|c|c|c|}
\hline \multirow{2}{*}{$\begin{array}{l}\text { Scientific name } \\
\text { of the plant }\end{array}$} & \multicolumn{4}{|c|}{ Concentration $(\mathrm{mg} / \mathrm{kg})$ of metals in plants } & \multirow[t]{2}{*}{ Reference } \\
\hline & $\mathrm{Cd}$ & $\mathrm{Pb}$ & $\mathrm{Cr}$ & Co & \\
\hline Spinach & $<0.06$ & 0.98 & $<0.05$ & 0.35 & \\
\hline Carrot & $<0.06$ & 0.72 & $<0.05$ & $<0.27$ & Jolly et al.[32] \\
\hline Radish & 0.65 & 0.51 & 1.68 & $<0.27$ & \\
\hline Cabbage & 0.18 & 3.82 & 0.43 & 0.14 & Gebrekidan et al., [33] \\
\hline Potato & 0.18 & 2.58 & 0.39 & 0.10 & \\
\hline Lettuce & 0.30 & 1.55 & 0.32 & 0.21 & \\
\hline Cabbage & 0.97 & 5.31 & - & - & Mohamed et al. [34] \\
\hline Potato & 0.99 & 6.19 & - & - & \\
\hline Cabbage & 1.79 & 7.14 & 4.33 & - & Jafarian et al.[35] \\
\hline Potato & 0.30 & $\mathrm{UDL}^{\mathrm{a}}$ & 6.00 & - & \\
\hline Lettuce & 1.79 & $\mathrm{UDL}^{\mathrm{a}}$ & 4.33 & - & \\
\hline Coriander & 0.01 & 0.40 & 4.20 & 0.20 & \\
\hline Radish leaf & 0.01 & 0.40 & 4.70 & 0.50 & Maleki et al.[36] \\
\hline Dill & 0.005 & 0.40 & 3.80 & 0.20 & \\
\hline Spinach & 15.24 & 16.20 & - & - & \\
\hline Cabbage & 2.97 & 13.01 & - & - & Yadav et al., [37] \\
\hline Radish & 18.92 & 17.26 & - & - & \\
\hline Cabbage & $1.2-2.5$ & $5.5-12$ & $<\mathrm{MDL}^{\mathrm{b}}-17$ & $5.7-9.7$ & \\
\hline Potato & $1.2-1.5$ & $5.4-7.8$ & $12-14$ & $5.2-8.7$ & Present study \\
\hline Khat & $0.4-3.2$ & $4.5-11$ & $9.0-15$ & $<\mathrm{MD}^{\mathrm{b}}-8.9$ & \\
\hline
\end{tabular}




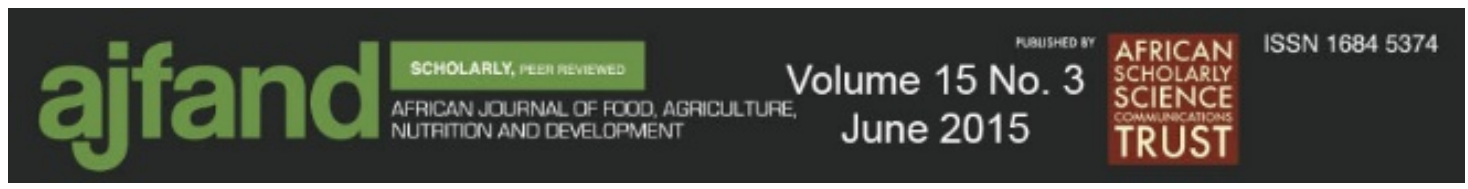

Table 6: Transfer factor of the Chemical elements

\begin{tabular}{lccccc}
\hline Chemical & Vegetables & \multicolumn{4}{c}{ Sites } \\
\cline { 3 - 6 } elements & & Harar & Aweday & Haramaya & HU \\
\multirow{3}{*}{ Chromium } & Cabbage & 0.25 & - & - & 0.41 \\
& Potato & - & 0.55 & - & 0.29 \\
& Khat & - & 0.36 & 0.31 & 0.35 \\
\multirow{3}{*}{ Cobalt } & Cabbage & 0.32 & - & 0.36 & 0.41 \\
& Potato & - & 0.25 & - & 0.37 \\
& Khat & - & 0.43 & - & 0.02 \\
\multirow{3}{*}{ Cadmium } & Cabbage & 1.39 & - & 1.46 & 0.96 \\
& Potato & - & 1.02 & - & 1.26 \\
& Khat & - & 0.8 & 0.48 & 1.26 \\
Lead & Cabbage & 0.45 & - & 0.21 & 0.25 \\
& Potato & - & 0.17 & - & 0.16 \\
& Khat & - & 0.14 & 0.22 & 0.23 \\
\hline
\end{tabular}

Table 7: Comparison of transfer factors (TF) for heavy metals from soil to vegetable tissues with similar and other edible plants from the literature

\begin{tabular}{lccccl}
\hline \multirow{2}{*}{ Name of the plant } & \multicolumn{2}{c}{ Concentration (mg/kg) of metals in plants } & \multirow{2}{*}{ Reference } \\
\cline { 2 - 5 } & $\mathrm{Cd}$ & $\mathrm{Pb}$ & $\mathrm{Cr}$ & $\mathrm{Co}$ & \\
\hline Amaranthus caudatus & - & 0.58 & 0.58 & 0.38 & Tyokumbur and \\
Corchrus olithorus & - & 1.20 & 0.46 & 0.37 & Okorie [31] \\
\hline Carrot & - & 0.048 & - & 0.020 & Jolly et al. [32] \\
Amaranthus & 1.161 & 0.064 & 0.02 & 0.036 & \\
\hline Cabbage & 0.25 & 0.56 & 0.01 & 0.01 & Gebrekidan et al. [33] \\
Potato & 0.26 & 0.78 & 0.01 & 0.01 & \\
\hline Cabbage & $0.96-1.46$ & $0.21-0.45$ & $0.25-0.41$ & $0.32-0.41$ & Present study \\
Potato & $1.02-1.26$ & $0.16-0.17$ & $0.29-0.55$ & $0.25-0.37$ & \\
Khat & $0.48-1.26$ & $0.14-0.22$ & $0.31-0.36$ & $0.02-0.43$ & \\
\hline
\end{tabular}




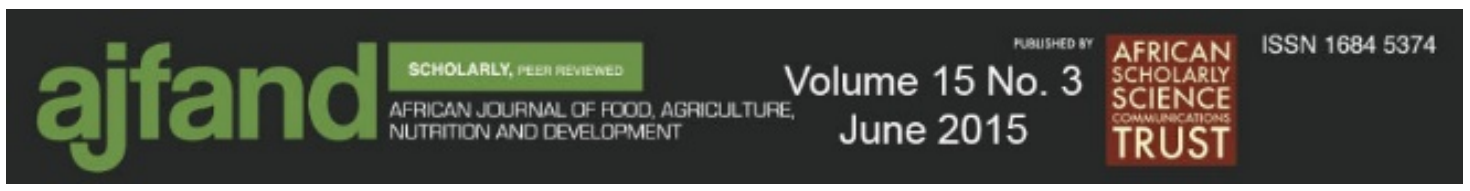

\section{REFERENCES}

1. Abdullah $\mathbf{M}$ and $\mathbf{J}$ Chmielnicka New aspects on the distribution and metabolism of essential trace elements after dietary exposure to toxic metals. Biological Trace Element Research 1990; 23: 25-53.

2. Mapanda F, Mangwayana EN, Nyamangara $\mathbf{J}$ and KE Giller The effect of long-term irrigation using waste water on heavy metal contents of soils under vegetables in Harare, Zimbabwe. Agriculture, Ecosystems \& Environment 2005; 107: $151-165$.

3. Khan MA, Ahmad I and R Inayatur Effect of environmental pollution on heavy metals content of Withania somnifera. Journal of the Chinese Chemical Society 2007; 54: 339-343.

4. Soomro MT, Zahir E, Mohiuddin A, Khan N and II Naqui Quantitative assessment of metals in local brands of tea in Pakistan. Pakistan Journal of Biological Sciences 2007; 1: 1-5.

5. Jarup L Hazards of heavy metal contamination. British Medical Bulletin, 2003; 68: $167-182$.

6. Awashthi SK Prevention of Food Adulteration Act. No. 37 of 1954. Central and State Rules as Amended for 1999, Ashoka Law House, New Delhi, 2000.

7. WHO/FAO. Food Standard Programme Codex Alimentarius (ALINORM 07/30/13). Report of the Thirty Eight Session of the Codex Committee on Food Hygiene, Houston, United States of America, 2007.

8. European Union (EU). Heavy Metals in Wastes, European Commission on Environment (http://ec.europa.eu/environment/waste/studies/pdf/heavy metal report.pdf), 2002.

9. $\quad$ FAO. Water Quality for Agriculture. FAO Irrigation and Drainage Paper 1985; 29: 1-120.UNESCO, Publication, Rome.

10. FAO/WHO. Food additives and contaminants, Joint FAO/WHO Food Standards Program; Codex Alimentarius Commission, ALINORM 01/12A:1-289, Geneva, Switzerland, 2001.

11. Jolocam M, Wasswa J, Kwetegyeka J and GK Bokyaita Heavy metal contamination in vegetables cultivated on a major urban wetland inlet drainage system of Lake Victoria, Uganda. International Journal of Environmental Studies 2010; 67: 333-348.

12. Anjula A and L Sangeeta A comparative analysis of trace metals in vegetables. Research Journal of Environmental Toxicology, 2011; 5: 125 - 132.

13. Allen SE, Grimshaw HM and AP Rowland Chemical analysis In Methods in Plant Ecology, edited by P.D. Moore and S.B. Chapman (Blackwell Scientific Publication, Oxford, London, 1986. 


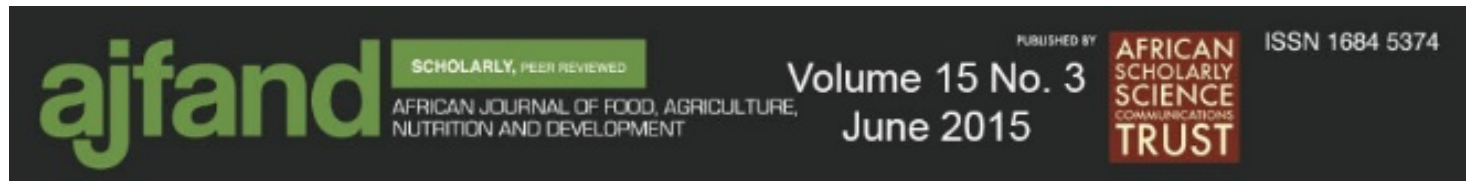

14. US Environmental Protection Agency (US EPA). Test Methods for Evaluating Solid Wastes, Physical/Chemical Methods, SW-846 Method 3005A, 3rd ed., Office of Solid Waste and Emergency Response, Washington D.C.

15. David AA and P Terry Limit of Blank, Limit of Detection and Limit of Quantitation. Clinical Biochemist Review, 2008; 29: 49-52.

16. Cui YJ, Zhu YG, Zhai RH, Chen DY, Huang YZ, Qui Y and JZ Liang Transfer of metals from near a smelter in Nanning, China, Environmental International 2004; 30: 785-791.

17. Miller JN and JC Miller Statistics and Chemometrics for Analytical Chemistry $6^{\text {th }}$ ed., Pearson, Harlow, England, 2010.

18. USEPA. Test method 7000B flame atomic absorption spectrophotometry. Retrieved October 10, 2011 from: http://www. epa. Gov / osw / hazard / testmethods / sw846/pdfs/7000b.pdf, 2007.

19. Amde M, Megersa N, Taddesse AM and T Bedassa Determination of the levels of selected metals in seeds, flowers and fruits of medicinal plants used for tapeworm treatment in Ethiopia. Toxicological \& Environmental Chemistry 2013; 95: 82-100.

20. Singh A, Sharma RK, Agrawal M and FM Marshall Health risk assessment of heavy metals via dietary intake of foodstuffs from the wastewater irrigated site of a dry tropical area of India. Food and Chemical Toxicology 2010; 48: 611619.

21. Mengel K and EA Kirby Principles of plant nutrition $5^{\text {th }}$ ed., Kluwer Academic Publishers, Dordretcht, the Netherlands, 2001.

22. Baize D Total contents of heavy metals in soils, INRA editions. France, Paris, 1997.

23. Kihampa C, Mwegoha JS and RS Shemdoe Heavy metals concentrations in vegetables grown in the vicinity of the closed dumpsite. International Journal of Environmental Sciences, 2011; 2: 889-895.

24. Khan MA, Ahmad I and R Inayatur Effect of environmental pollution on heavy metals content of Withania somnifera. Journal of the Chinese Chemical Society 2007; 54: 339-343.

25. Davies BE Cadmium in Heavy Metals in Soil, edited by B. J. Alloway, Blackie: Glasgow, 100, 1990.

26. Mohsen $\mathbf{B}$ and $\mathbf{S}$ Mohsen Investigation of metals accumulation in some vegetables irrigated with wastewater in Shahre Rey-Iran and toxicological implications. American-Eurasian Journal of Agriculture \& Environmental Sciences 2008; 4: 86-92. 


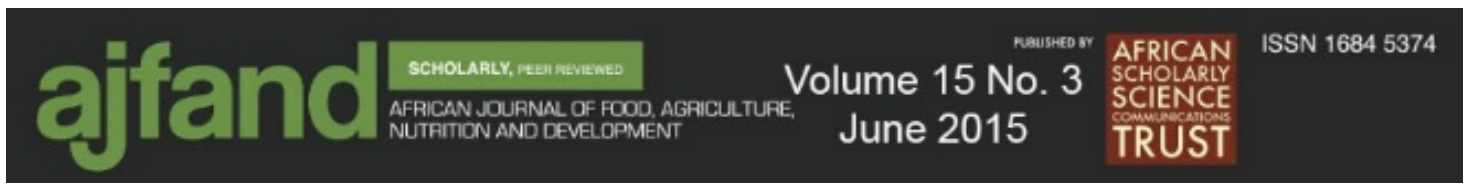

27. Wierzbicka M How lead loses its toxicity to plants. Acta Societatis Botanicorum Polaniae 1995; 64: 81-90.

28. Singh A, Sharma RK Agrawal and FM Marshall Risk assessment of heavy metal toxicity through contaminated vegetables from waste water irrigated area of Varanasi, India. Tropical Ecology 2010; 51: 375-387.

29. Lokeshwari H and GT Chandrappa Impact of heavy metal contamination of Bellandur Lake on soil and cultivated vegetation. Current Science 2006; 91: 620627.

30. Sajjad K, Robina, Shagufta S, Mohammad AK and S Maria Health risk assessment of heavy metals for population via consumption of vegetables. World Applied Sciences Journal 2009; 6: 1602-1606.

31. Tyokumbur ET and T Okorie Bioconcentration of trace metals in the tissues of two leafy vegetables widely consumed in Southwest Nigeria. Biological Trace Element Research 2011; 140: 215-224.

32. Jolly NY, Islam A and S Akbar Transfer of metals from soil to vegetables and possible health risk assessment. Springer Plus 2013; 2:385

33. Gebrekidan A, Weldegebriel Y, Hadera A and Bart Van der Bruggen Toxicological assessment of heavy metals accumulated in vegetables and fruits grown in Ginfel river near Sheba Tannery, Tigray, Northern Ethiopia. Ecotoxicology and Environmental Safety 2013; 95: 171 -178.

34. Mohamed HH Ali and Khairia M Al-Qahtani Assessment of some heavy metal sin vegetables, cereals and fruits in Saudi Arabian markets. Egyptian Journal of Aquatic Research 2012; 38: 31-37.

35. Jafarian DA and M Alehashem Heavy metal contamination of vegetables in Isfahan, Iran. Research in Pharmaceutical Sciences 2013; 8(1):51-58.

36. Maleki A, Amini H, Nazmara S, Zandi S and AH Mahvi Spatial distribution of heavy metals in soil, water, and vegetables of farms in Sanandaj, Kurdistan, Iran. Journal of Environmental Health Science \& Engineering 2014; 12(1):136145.

37. Yadav A, Yadav PK and DN Shukla Investigation of heavy metal status in soil and vegetables grown in urban areas of Allahabad, Uttar Pradesh, India. International Journal of Scientific and Research Publications 2013; 3(9): 1-7. 